\title{
Who am I, the religious educator? Religion in the formation of a moral compass
}

\author{
Monique van Dijk-Groeneboer ${ }^{1,2}$ (D)
}

Published online: 17 July 2020

(c) The Author(s) 2020

\begin{abstract}
The formation of identity in a secularized world is different from formation in a religious oriented society. In this situation, educating young people and guiding their personhood formation is even more a task of connecting to the pupils from out of your own heart. A Catholic religious teacher can be a mirror for these young people when answering three questions for her or himself and share these openly with her or his pupils. At the micro level: Who am I as a person? What is in my soul?; at the meso level: What am I doing as a professional and religious teacher?, and at the macro level: Where do I work? What is my context? And how do I deal with that?
\end{abstract}

Keywords Moral compass $\cdot$ Religious education $\cdot$ Identity $\cdot$ Teaching through religion

This article addresses the question of "Who am I, the religious educator?" It concerns both the teacher in secondary education and the instructor in tertiary education teacher training. The teacher or instructor's very self plays a significant role when the formation of (mostly young) people is the central goal. This immediately means something for the attitude and skills of the educator. The educator needs receptivity her or himself if the students are to open up and become more receptive. This openness and authenticity are an essential part of religious education (Baumfield 2015). Something is learned when those who take the role of educator upon themselves hold their experiences up as a mirror, or as an invitation to the students.

Pupils will have to be formed in such a way as to equip them to deal with the many choices that they have to make every day. In other words, they have to develop a moral compass. This compass will have to be a conscious set of values and motivational reasons that young people construct for themselves in today's world and which they can use in the future when faced with difficult choices. This article focuses particularly on the role religion, tradition and worldviews can play in secularized classrooms, whether the school subject is 'citizenship education', 'worldview education' or 'religious education'. Traditions that are rooted in the past have to be openly discussed in a genuine

Monique van Dijk-Groeneboer

m.c.h.vandijk@tilburguniversity.edu

1 Tilburg School of Catholic Theology, P.O. Box 80101, 3508 TC Utrecht, The Netherlands

2 Den Haag, The Netherlands 
dialogue in the classroom. The argument for this formation process will be based on research carried out by sociologists, practical theologians, and religious studies scholars in the Netherlands.

The concept of subjectification (Biesta 2018) is central to religious education. This means that the pupils are challenged to think who she or he wants to be as a person, as a subject. This is the third element in personhood formation inside religious education, along side formal qualifications; getting the knowledge you need and socialisation; getting connected to the world you live in and add positively to it. To that end, the religious educator must therefore know her or himself as a person and understand how s/he wants to stand in the world as a person; in other words, go through that process of subjectification. This is not just a theory, a cognitive process in the head, but it is about one's heart and soul; about the whole person. It is precisely there that the distinction emerges whether it is purely knowledge transfer, teaching about religion, and therefore in the head, or the formation of the whole person, teaching through religion, and therefore from and to the heart. When the later occurs, it is about the soul, the core, who you really 'Are' as a person, with an uppercase A. However, it will not work to ask this of pupils or students if you have not gone that way yourself.

So that is why in this article we first look at the micro level: who am I as a person? What is in my soul? Who do I want to be in the world? Who am I as a Catholic religious educator? I will look back to my own biography as an example and through my own story talk about my life and the formative and transformative aspects and the religious and spiritual influences that worked in it.

The second question is: What am I doing? Who am I as a religious educator? This is the meso level of our professional being. It is your vocation to do what you do, how and why you act in your occupational life as you do, and how the first micro level of your biography inspires and leads this professional being. It is from the heart and head to the hands; what you are actually doing.

The third part, the macro level, is the context in which you live and work, where you are. It is the organisation you work in, the church you belong to, the country you live in and the way you respond to this context. Your biography (micro) and your profession (meso) direct your actions towards this context (macro) and is also influenced by the context. Especially the way you act and think in this context completes your way of being.

Becoming aware of the connection between the three levels and the choices you make in life is the essential goal in this article. One's talents, one's actions and one's thoughts and judgments are one's moral compass.

The three levels, micro, meso, and macro, will be presented step by step allowing the possibility for the reader to consider those steps for themselves. The intent is that the religious educator begins to recognize elements of their own biography, profession and context in order to begin to respond to the question of who you are as a religious educator. Answering this question and following the three steps will make you aware of your own moral compass and in turn will provide the openness for others, such as your students, to do the same. Engaging with this in the classroom will stimulate a genuine dialogue and religious thinking through learning (Kienstra et al. 2018). Obviously, how to engage in this action, reflection and experience needs thorough attention, and the model of the hermeneutic space described by Sharkey might be helpful (Sharkey 2019).

This article hopes to assist religious educators into a deeper level of understanding of themselves and their professional being in their own context, and moreover make them aware of the rich diversity in context and biography that is often gathered in the educational space in which they work and how to deal with this fruitfully. The group can learn 
much from each other in the encounters and I hope educators will be inspired to allow to take these views into account when preparing for religious education in their own contexts.

\section{Micro level}

The first level, the micro level is: Who am I? What story do I have in my life? What aspects are formative and transformative? What are the religious and spiritual influences?

The first part of the biography forms the core of a person's existence and is the basis of one's awareness of self. It is important to be aware of this as a teacher first, before asking your pupils to go through the process.

Young people are often accused of being too individualistic. Being I-centred is often seen as something negative; something that prioritizes self-expression and self-interest, the 'fat-me' as it is sometimes called (Kunneman 2009). But being responsible for your actions and thoughts, and making choices is also a precious asset, as long as it is clear on what traditions and values the individual can and wants to base those choices, "by her- or himself". Later on, the connection to the 'we-centred' move is expressed when looking at the macro level of one's life.

In this first step you are invited to write down your own biography, from the heart in the way it comes to you now, at this very moment. The story you create differs every time you tell it and that is acceptable. It is important to record it beginning with your birth, the family you grew up in, the way you felt, if you can recall that, the part religion played in your life and the way this spiritual feeling developed over time.

I provide an example of my own life as an illustration.

I was born into a Catholic family in the 60's in the Netherlands. At that time, it was already quite special that I had my first holy communion (although I thought that was self-evident at the time), but especially my Confirmation at the age of 12 . I didn't think consciously about it myself ... it just went the way we were used to in our family. On Sunday we went to church, we prayed before and after dinner and we didn't actually talk about faith.

I was 16 when my father died. Yes, I felt abandoned and was very angry that he never came back. My family and friends seemed to expect it to be a turning point in my faith asking questions such as: "How can you believe in a god if this happens?" "How would a loving God let that happen?" Those were the questions of others. For me, my faith grew deeper because I noticed that God was with me in this sadness. The point was that I could find support to go through this, because it was certainly a tipping point, but in retrospect it was also a huge moment of growth.

More and more choices crossed my path: which courses would I choose for my final exam? Which subjects do I want to study? What do I want to do after graduating with these studies? Do I actually want this work? In retrospect, there has always been something that led me. The dot on the horizon ... a light ... I now call it God beckoning me to do 'the work' ... to be his hands ... to use my talents to bring his light into the world.

After completing this step, the written biography is the story of your life as you tell it today. It helps you to understand yourself when you use these reflections in the next steps. It has similarities with the Pedagogy of Encounter (Catholic Education Melbourne 2018) where individual stories are interpreted in the context of the world in which the pupils live. 


\section{Meso level}

The second level, the meso level, is the professional level, the job one does and the vocation one has.

In this step, one has to consider the job the educator is doing, the profession one has, the religious educator in oneself. Of course, everyone has to start with the biographical elements written down in the first step and see how these have influenced what a person is doing in their current work. What enables a person to do the job well? Where are the challenges?

Now you are invited to look at your biography written in the first step and focus on the level of the action; what are you doing in your life? For most readers this concerns the job they are in, the professional choices one made in life. Again, a short example might provide insight:

After high school, I chose to do 'something with people'; that's how I chose my studies in sociology and psychology. I was a girl who was good at mathematics, and my math teacher was not amused that I went into these 'soft sciences'.

Finishing my $\mathrm{PhD}$ on the social characteristics of technological improvements, I became aware that it would lead to a job that could bring me a lot of money, but it would not make me happy. I didn't know how to proceed. I was unemployed for two years, then, out of the blue I bought a newspaper that had a section advertising employment openings. There was an advertisement for a teacher in the sociology of religion, and being very active in my parish, both on the board as well as conducting the youth choir, I became immediately interested: here I could combine my education with my deepest passions. So, although I did not meet all the required characteristics, I applied for the job and I got it.

In my vocation today I want to bring people closer to their own souls and their life mission, closer to God, because I have experienced myself that it is a wonderful way to live and work. That's how I chose my work, or almost the way my work chose me. Now, I want others to learn from what I experienced by describing how this went and how I became who I am today. I educate teachers in Religion and Philosophy of Life and open them up to find their deepest vocation. I share with them the path I went myself. My compass in making choices was my faith and deep inner conviction that God has a plan with me, and I 'just' had to listen to this. And now writing this article as Professor of Religious Education...I think even my math teacher would be proud of me!

For the students you teach, this professional meso level of action is quite different. When entering this step in the classroom, the educator can ask their students what talents they discovered in their biography. What are their strengths? What are their weak spots? A digital questionnaire on strengths (such as www.strengthfinders.com) may assist young people who are less familiar with asking themselves these questions.

It is important here to give attention to the real narrative in their story, not only the physical, cognitive and psychological parts that already get quite some attention in the everyday life of the young person. They should be encouraged to become more aware of the deep roots in their lives and of their talents. The young are often not familiar with these spiritual and religious reflections.

In turn, what do educators actually know about the religion or faith of young people? How do young people relate to the transcendent, to that which lies beyond what is 
empirically perceptible? What do young people base their choices on in everyday life? Is there a direction, a horizon, which helps shape their identity? Can they find a source for the roots of their core values, so that they are firmly rooted in today's society? What is important to them when they make these moral choices? It might be helpful to engage in research focused on these questions, for this will bring about interesting concepts to work with in the RE classroom (van Dijk-Groeneboer 2017). Sharing their favourite music, the experience of going into nature, discussing their passion for sports seemed to be wonderful aspects to enter into their talents and future professional direction. In the Netherlands, this research has been conducted for over twenty years (van Dijk-Groeneboer and Maas 2001, 2005; van Dijk-Groeneboer and Van den Bosch 2008; van Dijk-Groeneboer and Brijan2013; van Dijk-Groeneboer and Van Herpen-de Regt 2019) and helps in developing activating exercises (Kienstra et al. 2018) described later in the paper.

It would be great to teach young people in Religious Education to make choices based on what is true to them, or rather on what is 'good' in life for them, so that they have a moral guideline to make responsible and fundamental choices. Religious Education must ensure that they acquire a language to reflect on this, to seek and further nurture the deeper roots of that knowledge. And it is important that there are people that they can talk to about this. People need to be able to spar with others about their ideas, in an open safe space. This brings us to the third level.

\section{Macro level}

The third level, the macro level, is about the context in which a person lives and works. After describing which choices are made in their personal life, which transformative moments are experienced and what the religious influences were in life, step one; and then realizing how one functions professionally as a religious educator, entering a job and following their vocation by educating, mentoring, and forming others, step two; then for step three, take a closer look at the context in which one does that. The school, university, church one works in, the city a person lives and works in, the country one was born in, and where one lives now. Moreover, a reflection on how one responds to this context from one's talents and actions is the crucial addition here. This may call to mind ethical issues as well: conflicts in one's personal and professional being, dealing with boundaries from the rules and norms in this context. Especially in this layer, the moral compass becomes clearer when focused on the lens a person uses. Because the story you describe in light of the person you are and the actions you take in this specific situation helps to bring about the judgments you make yourself when choosing your actions, and the compass on which you base these choices.

An extract from the author is provided here:

I live and work in the Netherlands. I live in a city called The Hague, nearby the sea, and I work in Utrecht and Tilburg, two inland middle-sized cities. In this country, religion, in the narrow sense is declining, as the drop in participation in religious activities such as church attendance shows. At the same time, however, the institutional form of religion is strongly present in society. Religion is in the news on a daily basis, especially when anxiety is mounting in society. Churches can expect media attention, but only bad news is news, at least in the Netherlands. The churches and their leaders are in the spotlight when cases of abuse come to light. The image of institutionalized religion is not positive. The images of religion that are used in the 
public domain are often superficial and at least incomplete. The image of religion and faith is not good.

Often I have to defend my position as being religious "even when I am intelligent and fully aware of what is happening in the world". Being a Catholic makes this worse, because the Pope and the strict rules on relationships, euthanasia and the value of human life are often in the news and very much criticised. Especially being a woman in a male-dominated church makes people ask what I think of women not being able to become priests. Being separated makes this more difficult, because many people judge from a religious context. I am often afraid to say this out loud.

In the university context, more men are in higher positions. So as a female professor, I want to be an example of how to deal with these issues and to be strong and inspiring as a woman.

These difficulties have not always been easy, and there were times I hardly could cope with it. But still I feel deep inside that God guides me through this darkness and difficult times. I could sense my roots that kept me standing while feeling swept away. God helps me to grow towards the light and to be the light of the world myself.

Educators are invited in this third step to look at the context in which they work. Does the environment assist their vocation to express the talents they have? What makes them rooted in difficult situations, especially when dealing with difficult ethical and moral issues? Here, the choices become clear when problems arise and ethical judgments are to be made. When encountering other opinions, you have to choose which road to follow, there has to be a guideline on which you base these choices. Making this third step helps to bring this essential mechanism to light.

When entering this third step in the classroom, one should invite young people to look at their context, to take the distant position of an outsider looking at the world they live in. This is not an easy or usual option for young people. It takes effort to allow this to happen, but it will help to get the sense of being part of a bigger world, of switching from the 'I-perspective' to the 'we-perspective'. Especially, looking at your life and actions helps you to see your world and the choices you make in becoming the person you want to be. This is the subjectification step mentioned in the introduction.

\section{Parallel process}

The three levels each highlight a part of the individual's moral compass. It is a constant encounter between experience, reflection and action (Sharkey 2019, p. 134). This entire process is a way from your heart through your head into your hands. First, there is the start of getting to know your talent, living from your core, your roots, your heart. This is knowing through the heart. It is feeling the eternal light, hearing God's word in you, being receptive and open.

Second, you become aware of these heart-issues by putting it into words or images if you prefer. This is the cognitive part: making connections in your head from your heart so you become aware of your deeply rooted values and talents. This second step is connecting your heart to your head; revealing your godly core to yourself. Or in other words letting God make you feel your own divine Light.

Third, the words or images of that talent and those qualities can be put into action, in your hands. By doing this, your talents can be used for the world, for the society, for the people around you. Then you are connected with the whole universe, God's creation, and 
you feel responsible for it. You start putting your talents through your head into action: doing good deeds, making choices for the right life, for the good in life.

Becoming aware of the process of combining the heart, the head and the hands is a benefit of working with these three steps. If one is able to reflect on this process in addition to the three levels, it will make the person a good example for all others; the teacher has the potential to open up others to enter this process.

\section{Developing a moral compass}

In this section, the Dutch situation is provided as an example of how we are trying to integrate the formation of a moral compass into the school RE class as well as in the education of RE teachers. The situation in Dutch schools, combined with the political pressure of $21^{\text {st }}$ century skills and citizenship education, highlights the need for developing strategies focused on value-learning lessons for secondary schools. The different types of young people in contemporary classrooms requires a new way of looking at religion (van Dijk-Groeneboer 2015). Opening up a dialogue in order to enter sacral experiences in everyday life as well as engaging with religions and worldviews is essential in developing a moral compass.

In this respect, we highlight the importance of 'theologizing' (Dillen and De Kock 2015) as an elaboration on philosophy for children ("P4C"). A term often used in Germanspeaking countries (Schambeck 2014; Schwarz 2006) in the empirical sense of 'religious thinking through' (Baumfield 2015), which is about eliciting theological statements based on human experiences and linked to traditions. Real dialogue will only be achieved when theologizing and the three steps provided above are combined (Roebben 2015). A moral compass is the inner core values one uses when looking at the world and reflecting on the experiences in the world. It resembles the framework Julie Mitchell described when examining reality, human nature, death and knowing (consciousness, MvD) (Mitchell 2004, p. 8). It is the glasses through which one looks at the world and judges and the way in which a person judges right and wrong.

Teachers could theologize by connecting each pupil's story to the great stories (Duffy and Cunningham 1996). This constructive way of teaching begins with the pupil and mediates her or his experience and life story through larger stories from religious traditions. Together, all encountering actors in the learning process search for religious core values. Such a process allows all participants to anchor themselves in traditional roots and respect each other more.

New frameworks for methods of religious teaching are developed by engaging in such practices (Pol et al. 2011). However, when engaging in the narrative dialogue about your roots, people become aware of what the word "together" means. In this way, RE is no longer merely a matter of 'looking at life' but is really about connecting to that which is meaningful, that which goes beyond what can be perceived empirically. It is also about connecting to life itself, about having values to base your actions on and being conscious of them. Moreover, it is about connecting with the people you live with and context in which you live; seeing them, understanding and respecting them in all their diversity and individuality.

An essential aspect for a teacher who is being trained at a teacher's academy is that she or he should do what they tell others to do: they should practice what they preach. To this end we developed inspirational days held at the start of our Master's program, in which teachers from our school and students who are training to become teachers formed 
a professional learning community. This is done using our colleagues' expertise and our students' input. In this way, together we develop new teaching methods for secondary education; we theologize together. These new methods are used by the internship students in school classes, and then faculty members research their effectiveness. A first pilot study of these new, self-designed forms of work was carried out in 2016 (Kienstra et al. 2018). For instance, Bibliodrama was introduced and students and teachers worked with it sharing their own encounters and dialogues. Following this new educational assignments were developed to bring this method into the classroom at secondary schools for six lessons. The results were examined via student questionnaires, teacher logs and classroom teaching materials. Scaffolds such as hinting, instructing, explaining, modelling and questioning were indicated by the students (p.208). New scaffolds were found that directed our attention towards higher order thinking skills such as listening, giving space and showing understanding. These scaffolds enabled the pupils to engage in a new way by thinking through religious education or theologizing. The above is an example of evidence-based lessons in Religious Education (van Dijk-Groeneboer et al. 2017) which helps pupils form their moral compass. Religious-thinking-through lessons assist pupils to become aware of their inner set of values and give them space to reflect on their judgments in exercises, and also in life.

First, Religious Education is necessary to fill the gap in pupils' knowledge about religious traditions, and to enable pupils to get to know 'lived religion', from the inside, people's soul and heart, and the function religion, tradition, play in people's lives. The traditions that are rooted in the past have to be openly discussed in a genuine dialogue in the classroom. This makes it easier for young people to better understand the concept of 'religion' in its broad sense.

Moreover, RE classes should invite young people to enter a narrative dialogue: to really look into their own biograph, to see when they had important decisions to make in their lives, and to determine how they came to make their decisions. How did these work out? Which values are core values for them? And how reliable are these values? Where could they obtain more information and sources to strengthen these values, examples of 'big stories' that can become examples for their own life's story...? There is an important role here for teachers and religious educators to open the minds of these young people to these issues and to allow them to grow and become strong. Young people need to develop a moral compass to be able to do so. Using the three levels described in this article proves to be a helpful way in constructing this compass. As the mentioned educational assignments show, when the teacher uses listening, showing understanding and giving space she or he opens up this sacred space for sharing ethical issues in the third, macro level of the three steps described.

However, it is difficult to work out the precise process of forming a personal moral compass. Pupils are encouraged to become self-aware of their set of values, by communicating with others and the teacher about them (micro level). Then they have to realise their set of values might be different from others, and they are to be critical on these values, explore possible alternatives and share experiences. In doing so, they realize the actions they perform emerge from their talents and internalized values (meso level). Then they also have to relate to the society and context close to them (macro level). This entire process is to take place without instructing the pupils how to build the compass. We have to avoid telling them how to think and feel, and yet we have to make them aware and communicate over highly abstract matters. Giving space, listening and showing understanding are higher order thinking skills and demand much more from the teacher. This takes time to develop and is a lifelong learning for teachers. They have to know their values themselves, also in relation to other people and their values, 
and they have to be able to communicate this. Moreover, they have to be willing to open up themselves towards their students, which makes them vulnerable. There has to be a safe space in the classroom, to start with. Religious traditions and worldviews are to be offered at right times in the dialogue and hermeneutics are necessary to deal with these rich traditions containing texts and rituals.

The moral compass that a person develops will be re-shaped continuously throughout their life, as they come in contact with others they clarify and refine their own values. It is a great opportunity to let young people develop this compass, reflect on it, and teach them tools to keep thinking about this compass throughout their lives. It will make them stronger and happier, and the world as a whole will benefit.

\section{Conclusion}

In this article, a path of three steps has been followed to describe the way a moral compass comes about and is shaped by connecting it to others. At the micro level a biographical reflection on life issues focuses on a person's narrative; who am I? At the meso level, their talents are depicted, what are a person's unique qualities, strengths, and what does this tempt the person to do in his or her life? At the macro level, one relates to the context one lives in; how to put the strengths and the personal experiences in connection with the people you encounter and add to the world you live in? And how do you feel and think about doing so? In Dutch secondary schools and teacher academy this process of formatting a moral compass seems to work.

Moreover, you often only see something like this when you review your life. If you reflect on your own life story, you see where you make choices and how your compass steered at that moment as well as to which dot on the horizon you are heading. If we develop that compass consciously and openly, pupils and students can in turn do the same. You develop that compass by really listening to the stories of others. The story of the other helps a person to view one's own story, as we have practised in the steps provided. Looking through the eyes of the other provides a clear view on one's own perspective, of the glasses one wears when one looks at one's life, one's profession and the context in which one lives and works. It is also helpful to engage with the stories of the old traditions because people have been making choices for as long as we know there were people. We can learn about our own compass and choices to be made through listening to the stories of others, in the here and now as well as in the past.

Thereby, we now have arrived at a time where we can consciously do that. For we are aware that human beings are making choices in a moral way, based on what is in the heart and led by the spirit. And the world of today is in need of such transformation. The young people who are growing up now are in someway prepared to connect to that spirit, make those choices, to sail on that deep course, to focus on the light.

It is our job as religious educators to help our pupils and students to travel from the heart through the head into their hands, to make them open for the call God has for them, to hear that voice and act on it. Hopefully the reader experienced it in this article by connecting to the three levels in the steps provided.

Open Access This article is licensed under a Creative Commons Attribution 4.0 International License, which permits use, sharing, adaptation, distribution and reproduction in any medium or format, as long as you give appropriate credit to the original author(s) and the source, provide a link to the Creative Commons 
licence, and indicate if changes were made. The images or other third party material in this article are included in the article's Creative Commons licence, unless indicated otherwise in a credit line to the material. If material is not included in the article's Creative Commons licence and your intended use is not permitted by statutory regulation or exceeds the permitted use, you will need to obtain permission directly from the copyright holder. To view a copy of this licence, visit http://creativecommons.org/licenses/by/4.0/.

\section{References}

Baumfield, V. (2015). Thinking through religious education. Cambridge: Chris Kington Publishing.

Biesta, G. (2018). Tijd voor pedagogiek. Utrecht: Universiteit van Humanistiek.

Catholic Education Melbourne. (2018). Religious education curriculum framework. www.resourceme lb.catholic.edu.au.

Dillen, A., \& A. De Kock (Eds.). (2015). Theologiseren met kinderen themanummer van. Handelingen, 42(4), 3-6.

Duffy, T. M., \& Cunningham, D. J. (1996). Constructivism: Implications for the design and delivery of instruction. In D. H. Jonassen (Ed.), Handbook of research for educational communications and technology. London: Prentice Hall International.

Kienstra, N., van Dijk-Groeneboer, M., \& Boelens, O. (2018). Religious thinking through using bibliodrama: An empirical study of student learning in classroom teaching. Religious Education, 113(2), 203-216.

Kunneman, H. (2009). Voorbij het dikke-ik. Amsterdam: Uitgeverij S.W.P.B.V.

Mitchell, J. (2004). Teaching about world views and values. Melbourne: Council for Christian Education in Schools.

Roebben, B. (2015). Inclusieve godsdienstpedagogiek: Grondlijnen voor levensbeschouwelijke vorming. Leuven: Acco.

Schambeck, M. (2014). Das ist ein durchsichtiges Paket, was überall durch kann. Prinzipien des Theologisierens mit (religionsfernen) Kindern. In G. Büttner \& F. Kraft (Eds.), 'He! Ich habe viel Stress! Ich hasse alles': Theologisieren mit Kindern aus Bildungs- und religionsfernen Milieus (pp. 44-53). Stuttgart: Calwer Verlag.

Schwarz, E. (2006). Philosophieren und Theologisieren mit Kindern: Ein Akademielehrgang. In A. Bucher, G. Büttner, P. Freudenberger-Lötz, \& M. Schreiner (Eds.), 'Vielleicht hat Gott uns Kindern den Verstand gegeben': Ergebnisse und Perspektiven der Kindertheologie (pp. 173-181). Stuttgart: Calwer Verlag.

Sharkey, P. (2019). Religious education as a catholic hermeneutic space. In R. Rymarz \& P. Sharkey (Eds.), Moving from theory to practice (pp. 123-140). Mulgrave: Vaughan Publishing.

van de Pol, J., Volman, M., \& Beishuizen, J. (2011). Patterns of contingent teaching in teacher-student interaction. Learning and Instruction, 21, 46-57.

van Dijk-Groeneboer, M. C. H. (2015). Youth ministry-About youth? Journal of Youth and Theology, 14(1), 25-45.

van Dijk-Groeneboer, M. (2017). Inspirerende lessen. Tilburg University, Utrecht.

van Dijk-Groeneboer, M., \& Brijan, B. (2013). Kerk uit zicht? Jongeren inspireren!. Tilburg: Faculteit Katholieke Theologie Tilburg.

van Dijk-Groeneboer, M., \& Maas, J. (2001). Op Zoektocht: Levenslang!. Utrecht: Katholieke Theologische Universiteit.

van Dijk-Groeneboer, M., \& Maas, J. (2005). Geloof? Ff checke!. Utrecht: Katholieke Theologische Universiteit Utrecht.

van Dijk-Groeneboer, M., Maas, J., \& Van den Bosch, H. (2008). Godsdienst? Lekker belangrijk!. Tilburg: Faculteit Katholieke Theologie Tilburg.

van Dijk-Groeneboer, M., \& Van Herpen-de Regt, B. (2019). Jongeren en hun waarden. Religie en Samenleving, 14(2), 144-174.

Publisher's Note Springer Nature remains neutral with regard to jurisdictional claims in published maps and institutional affiliations. 